\title{
Ceci n'est pas un subalterne. A Comment on Indigenous Erasure in Ontology-Related Archaeologies
}

\author{
Beatriz Marín-Aguilera \\ McDonald Institute for Archaeological Research, University of Cambridge, Cambridge, UK. Email: bm499@cam.ac.uk
}

\begin{abstract}
Having followed with great interest the latest scholarly literature on ontology-related archaeologies, especially in this journal, this essay will problematise the extractive nature of much of this scholarship in the long-history of Western imperialism, in which Indigenous knowledge has been collected, depoliticised, classified, and then re-signified within Western frameworks.
\end{abstract}

Keywords: Indigenous knowledge; archaeologies of ontology; intellectual appropriation; subalternity; performativity and citational practices; situatedness

Having followed with great interest the latest scholarly literature on ontology-related archaeologies, especially in this journal (e.g. Barrett 2014; Cipolla 2018; Hodder and Lucas 2017; Lindstrøm 2015; Olsen and Witmore 2015), this essay will problematise the extractive nature of much of this scholarship in the long history of Western imperialism, in which Indigenous knowledge has been collected, depoliticised, classified, and then re-signified within Western frameworks. This is something Indigenous scholars and non-scholars have voiced countless times, but it has been disregarded. I therefore use my position of privilege (white European and researcher at the University of Cambridge) as ally to support and amplify their voices.

\section{Some introductory remarks}

For the last 40 years, the increasing awareness that life as we know it is coming to an end (the Covid-19 pandemic has only strengthened this feeling) is forcing many to question the economic, political, and philosophical foundations of our societies that have brought us to this dramatic situation. In this context, resorting to other (Indigenous) ways of knowing and of being in the world is seen as an alternative to solve our problems.

Scrambling for answers to question the ruins of the established Cartesian and colonial roots of the disciplines of archaeology and anthropology, 'object-oriented' and 'new animist' scholars have 'discovered' other -more symmetrical- ways of understanding and being in the world and have crafted them for Western audiences, gaining in the process considerable symbolic and academic capital. In an unexpected turn of events, it seems that the 'Indigenous/subaltern/non-modern' is helping the 'modern' -in this case Western anthropologists and archaeologists- to cope with the destruction of their own world, as if the subaltern can now save scholars from their own theoretical deadlocks (Mendoza 2018). 


\section{Cognitive extraction}

The West has gone from imperial socioeconomic extraction since the late 15th century to the inclusion of novel forms of extraction in the late 1980s, such as intellectual appropriation (Ndlovu 2014; Rivera Cusicanqui 1987, 2010; Simpson and Klein 2013). Extraction, as a fundamental colonial project, is removing 'all of the relationships that give whatever is being extracted meaning. Extracting ... is stealing - it is taking without consent, without thought, care or even knowledge of the impacts that extraction has on the other living things in that environment' (Simpson and Klein 2013). Immersed in a mixture of homogenisation and othering/exoticisation, object-oriented and new animist theories praise the radical ontologies of Indigenous people whilst depoliticising them and/or not properly acknowledging the authors/origins of such worldviews. In doing so, they reiterate the subalternisation of subalterns, in this case Indigenous communities.

Subalternity is a performative act in this sort of archaeological discourses. It is not only a social constraint, but has to be conceived of as having a performative power. As with the idea of sex, our narrative(s) of subalternity has 'the power to produce -demarcate, circulate, differentiate- the bodies it controls' (Butler 1993, 2). The continuous reiteration of subalternity in ontology-related archaeologies produces and stabilises, consciously or unconsciously, the very effects of subalternity (Butler 1993, ix). Subalternity is, in this way, a speech act (Butler 1993, xxi).

In fact, scholarly appropriations of Indigenous knowledge are becoming increasingly institutionalised after stripping them of their socioeconomic contexts and political effects (Briggs 2005, 111; Mendoza 2018, 117; Simpson and Klein 2013; Smith 1999). The inclusion of local voices in academic publications and discourses is recently seen, contrarily to the past, as crucial for development programmes and sustainable approaches to nature (Briggs and Sharp 2004; Escobar 2007; Radcliffe 2014), as well as for decolonising archaeology and anthropology (Alberti et al. 2011; Atalay 2012; Descola 2005; Gnecco 2012; Haber 2016; Henare et al. 2007; Ingold 2013).

To be clear, I agree that Indigenous knowledge(s) needs to break into archaeological (and anthropological) discourses to take 'its own place in history, so that the subaltern is not merely protected by "negative consciousness" (Spivak 2005, 478, my emphasis). Instead of doing this, I argue that the introduction of Indigenous knowledge is very often drawn into archaeology in a very limited way, failing to engage with and to articulate a robust critique of unequal power relations and knowledge production in our discipline. This has reinforced Indigenous people as the West's 'self-consolidating Other', in a process that Spivak called the 'hyperbolic admiration or ... pious guilt that today is the mark of a reverse ethnocentrism' (Spivak 1988a, 272).

Reverse ethnocentrism produces the 'benevolent double bind' of 'considering the "native" as object for enthusiastic information-retrieval and thus denying its own "worlding"' (Spivak 1985, 245). In Linda Tuhiwai Smith's words, 'the West can desire, extract and claim ownership of our [Indigenous] ways of knowing, our imagery, the things we create and produce, and then simultaneously reject the people who created and developed those ideas and seek to deny them further opportunities to be creators of their own culture and own nations' $(1999,1)$. This is particularly the case of object-oriented archaeologies and new animism, which have strongly entered anthropological and archaeological debates in the last twenty years.

\section{Reverse ethnocentrism and denial of 'worlding'}

The concept of 'flat ontology' (DeLanda 2002; Latour 1993), the basis of both new animism and symmetrical archaeology (and generally New Materialisms), invites us to take symmetry seriously, which means to accept a non-hierarchical apriorism in which all things -animals, plants, objects, humans, etc.- interact with each other having the same degree of being-ness (Edgeworth 2016; Olsen and Witmore 2015; Thomas 2015; Witmore 2014). These theories are grounded to a greater or lesser extent in Indigenous worldviews/stories/epistemologies that have been shared and kept alive by Indigenous peoples for centuries, and in many cases published (see, for instance, 
Huanacuni Mamani 2010; Little Bear 2000; Nanculef Huaiquinao 2016; Simpson and Klein 2013; Smith 1999; Yampara Huarachi 2011). Now, even if Latour embraces an ethnographic ethic in his insistence that humans are not the main actors in this world, he neither recognises nor cites any Indigenous thinker in his work (Todd 2016). A similar critique has been directed towards famous anthropologists such as Viveiros de Castro or Holbraad (Hunt 2014; Mendoza 2018; Sundberg 2014; V. Watts 2013), to whom archaeologies of the 'ontological turn' are indebted to different degrees (Alberti et al. 2011; Domańska 2014; Henare et al. 2007; C. Watts 2013; Wilkinson 2017). To be sure, these are the same anthropologists and archaeologists who argue for the existence of multiple and distinctive ontologies, but they barely cite any Indigenous scholar in their work. The subaltern is thus filtered through white intermediaries who act on behalf of her/him (Sundberg 2014; Todd 2016, 7), rendering scholarly representations unproblematic and confirming once again Spivak's distress: even when the subaltern can speak, (s)he cannot be heard (Spivak 1988b, 308).

Western scholars look at alternate-Indigenous ideas of co-constitutive relations between objects, nature, animals and humans to help them renew the discipline and even the world, but on their terms, they homogenise and generalise Indigenous worldviews which are far more complex than the scholars' understanding of them and not as symmetrical as claimed to be (Franco 2012; Mendoza 2018). By filtering and misinterpreting local theories/stories, new animists essentialise conceptions building a pan-Indigenous epistemology that does not exist. Viveiros de Castro is a case in point, whose 'Amerindian perspectivism' makes uniform Indigenous' ingenuity and skids 'into the terrain of reductionism, oversimplification, and overinterpretation', ignoring the specific historical trajectories of each Indigenous group (Ramos 2012, 483). He also seems to communicate only the 'perspective' of men, showing a complete disregard for gender issues (Wainberg 2021).

Most importantly, anthropologists and archaeologists' new theoretical frameworks have little concern for actual Indigenous people and their struggles (cf. Braun 2019; Jofré 2015; Paillalef Carinao 2011; Ramos 1994; Rivera Cusicanqui 2010; Smith et al. 2018). As Chandler and Reid point out, 'What is at stake is the capacity of indigenous ways of knowing to take alterity the nonhuman - seriously rather than the anthropologists' capacity to take indigeneity seriously. If the latter were the case, the focus would not be on the problems of the modern episteme but on the problems facing real indigenous groups in their struggles over rights, representation and resources' (Chandler and Reid 2018, 259; see also Mendoza 2018, 116; Politis 2001, 96-101; Rivera Cusicanqui 2010, 53-76). This is precisely the denial of 'worlding' that Spivak talks about. Archaeology as it is widely practiced cannot escape its constitutive relations of dominion over the subaltern subject 'on the other side of the international division of labour, [who] cannot speak ... even if the absurdity of the nonrepresenting intellectual making space for her to speak is achieved' (Spivak 1988a, 289). It is also within this context that we should reflect on the reiterative practices of our discourses that end up engendering yet even more violence towards subalterns.

\section{Speech acts}

Calls for archaeologists to 'unite in a defence of things, a defence of those subaltern members of the collective that have been silenced and 'othered' by the imperialist social and humanist discourses' (Olsen 2003, 100, my emphasis); or statements such as 'things are not merely enslaved in some wider system of differential meaning, but possess their own capacities and inhabit their own compartments' (Olsen et al. 2012, 16, my emphasis; see also Latour 1993, 80), should be scrutinised in light of real subaltern and Indigenous struggles.

Beyond doubt, symmetrical archaeology has provocatively challenged and advanced our understanding of objects on their own right (Olsen 2010; Olsen et al. 2012; Pétursdóttir and Olsen 2018; Webmoor 2007; Witmore 2014). Yet, referring to neglected things as 'subaltern', 
'othered' and 'enslaved' stabilise even further the effects of subalternity. To be sure, when we talk about subaltern communities, we refer to people who have experienced slavery, racism, gender discrimination, dispossession, and/or forced displacement. Many times, these experiences were fatal. Are we really equating those experiences with not paying sufficient attention to the uniqueness of a Neolithic pot?

What is more, associating subalternity with objects whilst ignoring/silencing real subalterns is a disgraceful speech act: it shapes realities that subalternise even more subaltern people and their experiences. Objects are not subalterns. Such identification is not only extremely dehumanising, but it reinforces and supports once again the colonial and expansionist agenda of many countries and ethnic majorities, in the views of whom Indigenous people are terrorists, as in the case of the Mapuche in Chile (Millaleo 2021; Pairican and Urrutia 2021); 'wild animals', as in the case of the Gumuz in Ethiopia (González Ruibal 2014, 92); or simply non-existent, as in the case of the Akha, Dara'ang, Hmong, Iu-Mien, Kachin, Karen, Lahu, Lisu, Lua and Shan in Thailand (Morton 2017), to name only few examples. Equating objects with people as subalternised Others -being spoken for/vertreten (Spivak 1988b)- by archaeologists has severe ethical slippages, to say the least. Still, for Olsen and Witmore, 'assessing the world by ethical principles that restrict us to human fraternity, however well-meaning, is disquieting.' (Olsen and Witmore 2015, 192). What is surely disquieting is to conflate human suffering with arguably overlooked objects by using the same utterance and applying the same postcolonial rhetoric, as well as to objectify people and flatten the notion of the social by deleting inequalities and power relations (Pollock et al. 2014, 156-57). Ontology-related archaeologies also contrast with the efforts of many archaeologists working together with Indigenous communities around the world. The former, aware of their position of privilege, try to build decolonising narratives about the past based on Indigenous perspectives (see, for instance, Atalay 2006; Cipolla et al. 2019; Colwell 2016; McNiven 2016; Gnecco and Ayala 2011; Smith and Wobst 2005).

The turn away from humans enacted by ontology-related archaeologists is the product of unaddressed postcolonial demands, which leads archaeologists, consciously or unconsciously, to avoid confronting Indigenous' critiques of our work and of our power to endlessly represent them and the past -a point rightly made by Severin Fowles (2016). Things, and the scientific analysis of things, are far less controversial than Indigenous claims -or than studying people for that matterhence the recent focus on them in both anthropology and archaeology (Fowles 2016; Harris and Cipolla 2017, 198-200; Preucel 2020; 2021).

\section{Situated knowledge}

Disregarding the social and, especially, the 'worlding' that Spivak warns us about also leads us to hide our privileged position in the conception of theory and interpretations. If we are to take Indigenous ontologies seriously (Alberti 2016; Alberti and Marshall 2009; Haber 2016; Wilkinson 2017), we should start by letting their views drive our work rather than citing only Western scholars who have filtered and depoliticised Indigenous thought. There are many Indigenous scholars who publish themselves and do not need academic ventriloquism. Acknowledging how Indigenous ontologies have framed New Materialisms in substantial and different ways is not only ethical, but an Indigenous right: see Art.11 of the UN Declaration on the Rights of Indigenous People regarding Indigenous intellectual property and the project Intellectual Property Issues in Cultural Heritage (IPinCH) led by George Nicholas. Citational practices are important, as it is situated knowledge(s).

The mobility of theory is a case in point. In a beautifully written prose, Pétursdóttir and Olsen (2018) state that theories 'are not natives confined to any particular territory, but nomads in a mixed world, always accommodating themselves to shifting local conditions... Borrowing is an art of keeping theory alive' (Pétursdóttir and Olsen 2018, 114-15). Yet, theories are always 'natives' insofar as they have been created in a context and by a particular person or group of 
people -who happen to be, most of the times from the West, and particularly British and US-American, although the situation is fortunately changing (Olsen 2012, 18-19). Further, theories' nomadism often conceals power asymmetries that pervade their adoption -even if transformed- by other locales.

The very act of disregarding the politics of bio- and geopolitical locations, and their effects and affects in the creation and transformation of theories, is a performative practice that normalises power asymmetries and subalternisation (Franco 2012; Grosfoguel 2016; Haraway 1988; Rivera Cusicanqui 1987; 2010, 55-69; Smith 1999; Sundberg 2014). These types of theories that render invisible their loci of enunciation are also incapable of acknowledging the epistemic violence through which (western) archaeologists come to have the theoretical and institutional foundations through which the encounter with the Indigenous Other is initiated and to which it returns (Radcliffe 2014; Smith 1999; Todd 2016).

Hence, the point of origin of theories does matter and, in most cases, borrowing is not so much 'an art of keeping theory alive' as a hegemonic practice in academia, as the (mis)appropriation of Indigenous knowledge demonstrates (Sundberg 2014; Todd 2016; see also Hamilakis 2005, 98; Lins Ribeiro 2014; Neustupný 1998; Politis 2001). English linguistic imperialism and AngloUS academia -and high-ranking journals for that matter- have subalternised and silenced many scholars who think and write in other non-privileged languages and from different geopolitical locations. Privilege is here a sort of insularity that cuts off the privileged agent from certain kinds of 'other' knowledge(s).

\section{Conclusion}

Failing to address the epistemic violence against Indigenous people, and to create a responsible and reciprocal relationship with them when using and applying their knowledge, not only delegitimises Indigenous communities but also perpetuates the colonial extractive endeavour and strengthens the subalternisation to which they have been subjected for many centuries. Recognition is here a guiding principle, as it is unlearning/undoing our privileges (Butler 2004; Danius et al. 1993). We should seek a genuine answer to the question posed years ago by the Aymara Simón Yampara Huarachi: is academia interested in cultivating other sources of creating knowledge, of doing science? $(2011,11)$; to which I would add, is academia really interested in responsibly and reciprocally learning from and acknowledging those knowledges?

Acknowledgements. I am sincerely grateful to Juana Paillalef for her support during my fieldwork in Chile, and for trusting me to share her experience and knowledge about community museums in general and about the Mapuche in particular. I also thank Dominica Quilapi, who during a weaving class made me confront my privileges in a way I had not done it before. My gratitude goes as well to the two anonymous reviewers for their very positive feedback on a previous manuscript of this article and their valuable comments, which helped me sharpen my argument.

\section{References}

Alberti, B., 2016: Archaeologies of ontology, Annual Review of Anthropology 45, 163-79.

Alberti, B., S. Fowles, M. Holbraad, Y. Marshall and C. Witmore, 2011: 'Worlds otherwise': Archaeology, anthropology, and ontological difference, Current Anthropology 52(6), 896-912.

Alberti, B. and Y. Marshall, 2009: Animating archaeology: Local theories and conceptually open-ended methodologies, Cambridge Archaeological Journal 19(3), 344-56.

Atalay, S., 2006: Indigenous archaeology as decolonizing practice, The American Indian Quarterly 30(3), 280-310.

Atalay, S., 2012: Community-based archaeology: Research with, by, and for indigenous and local communities. Berkeley.

Barrett, J.C., 2014: The material constitution of humanness, Archaeological Dialogues 21(1), 65-74.

Braun, S.F., 2019: Culture, resource, management, and anthropology: Pipelines and the 'wakan' at the Standing Rock Sioux Reservation, Plains Anthropologist, 1-18.

Briggs, J., 2005: The use of indigenous knowledge in development: problems and challenges, Progress in Development Studies 5(2): 99-114. 
Briggs, J. and J. Sharp, 2004: Indigenous knowledges and development: a postcolonial caution, Third World Quarterly 25(4), 661-76.

Butler, J., 1993: Bodies that matter: On the discursive limits of 'sex', London.

Butler, J., 2004: Precarious life: The powers of mourning and violence, London.

Chandler, D. and J. Reid, 2018: 'Being in being': Contesting the ontopolitics of indigeneity, The European Legacy 23(3), 251-68.

Cipolla, C.N., 2018: Earth flows and lively stone. What differences does 'vibrant' matter make?, Archaeological Dialogues 25(1), 49-70.

Cipolla, C.N., J. Quinn and J. Levy, 2019: Theory in collaborative Indigenous archaeology: Insights from Mohegan, American Antiquity 84(1), 127-42.

Colwell, C., 2016. Collaborative archaeologies and descendant communities, Annual Review of Anthropology 45, 113-27.

Danius, S., S. Jonsson and G.C. Spivak, 1993: An interview with Gayatri Chakravorty Spivak, Boundary 2 20(2), 24-50.

DeLanda, M., 2002: Intensive Science and Virtual Philosophy, London.

Descola, P., 2005: Par-delà nature et culture, Paris.

Domańska, E., 2014: Retroactive ancestral constitution and alter-native modernities, Storia della Storiografia 65(1), 61-75.

Edgeworth, M., 2016: Grounded objects. Archaeology and speculative realism, Archaeological Dialogues 23(1), 93-113.

Escobar, A., 2007: Worlds and knowledges otherwise, Cultural Studies 21(2/3), 179-210.

Fowles, S., 2016: The perfect subject (postcolonial object studies), Journal of Material Culture 21(1), 9-27.

Franco, L.G., 2012: Arqueología sin-métrica. Elementos para una discusión desde el Sur. Ponencia presentada en la VI Reunión de Teoría Arqueológica en América del Sur. Unpublished paper: https://bit.ly/3hRez6r. Accessed 10/04/2014.

Gnecco, C., 2012: Arqueología multicultural. Notas intempestivas, Complutum 23(2), 93-102.

Gnecco, C. and P. Ayala (eds.), 2011: Indigenous peoples and archaeology in Latin America. Walnut Creek, CA: Left Coast Press.

González Ruibal, A., 2014: An archaeology of resistance: Materiality and time in an African borderland. Plymouth: Rowman and Littlefield.

Grosfoguel, R., 2016: Del «extractivismo económico» al «extractivismo epistémico» y «extractivismo ontológico»: una forma destructiva de conocer, ser y estar en el mundo, Tabula Rasa 24, 123-43.

Haber, A., 2016: Decolonizing archaeological thought in South America, Annual Review of Anthropology 45, 469-85.

Hamilakis, Y., 2005: Whose world and whose archaeology? The colonial present and the return of the political, Archaeologies 1(2), 94-101.

Haraway, D., 1988: Situated knowledges: the science question in Feminism and the privilege of partial perspective, Feminist Studies 14, 575-99.

Harris, O.J.T. and C.N. Cipolla, 2017: Archaeological theory in the new millennium: Introducing current perspectives. Oxon.

Henare, A., M. Holbraad and S. Wastell, 2007: Introduction: thinking through things, in A. Henare, M. Holbraad and S. Wastell (eds.), Thinking through things: Theorising artefacts ethnographically, London, 1-31.

Hodder, I. and G. Lucas, 2017: The symmetries and asymmetries of human-thing relations. A dialogue, Archaeological Dialogues 24(2), 119-37.

Huanacuni Mamani, F., 2010: Buen vivir/Vivir bien. Filosofía, políticas, estrategias y experiencias religiosas andinas. Lima: Coordinadora Andina de Organizaciones Indígenas.

Hunt, S., 2014: Ontologies of indigeneity: The politics of embodying a concept, Cultural Geographies 21(1), 27-32.

Ingold, T., 2013: Making: Anthropology, archaeology, art and Architecture, New York.

Jofré, C., 2015: The mark of the Indian still inhabits our body. On ethics and disciplining in South American archaeology, in A. Haber and N. Shepherd (eds.), After ethics: Ancestral voices and postdisciplinary worlds in Archaeology, New York, 57-78.

Latour, B., 1993: We have never been modern, Cambridge.

Lindstrøm, T.C., 2015: Agency in itself. A discussion of inanimate, animal and human agency, Archaeological Dialogues 22(2), 207-38.

Lins Ribeiro, G., 2014: World anthropologies: Anthropological cosmopolitanisms and cosmopolitics, Annual Review of Anthropology 43, 483-98.

Little Bear, L., 2000: Jagged worldviews colliding, in Reclaiming Indigenous voice and vision, ed. M. Battiste. Vancouver: University of British Columbia Press, 177-85.

McNiven, I., 2016: Theoretical challenges of Indigenous archaeology: Setting an agenda, American Antiquity 81(1), $27-41$.

Mendoza, B., 2018: Can the subaltern save us?, Tapuya: Latin American Science, Technology and Society 1(1), 109-22.

Millaleo, S., 2021: Por una vía "chilena" a la plurinacionalidad: intervenciones de una década (2010-2020). Santiago de Chile: Catalonia.

Morton, M.F., 2017: Reframing the boundaries of Indigeneity: State-based ontologies and assertions of distinction and compatibility in Thailand, American Anthropologist 119(4), 684-96.

Ñanculef Huaiquinao, J., 2016: Tayiñ Mapuche Kimün. Epistemología Mapuche - Sabiduría y conocimientos. Santiago de Chile: Universidad de Chile.

Ndlovu, M., 2014: Why indigenous knowledges in the 21st century? A decolonial turn, Yesterday and Today 11, 84-98.

Neustupný, E., 1998: Mainstreams and minorities in archaeology, Archaeologia Polona 35-36, 13-23.

Olsen, B., 2003: Material culture after text: Re-membering things, Norwegian Archaeological Review 36(2), 87-104. 
Olsen, B., 2010.: In defense of things: Archaeology and the ontology of objects. Lanham, MD: Altamira Press.

Olsen, B., 2012: After interpretation: Remembering Archaeology, Current Swedish Archaeology 20, 11-34.

Olsen, B., M. Shanks, T. Webmoor and C. Witmore, 2012: Archaeology: The discipline of things. Berkeley, CA: University of California Press.

Olsen, B. and C. Witmore, 2015: Archaeology, symmetry, and the ontology of things: A response to critics, Archaeological Dialogues 22(2), 187-97.

Paillalef Carinao, J., 2011: The message of the Kuviche in the Llew-Llew, in Indigenous peoples and archaeology in Latin America, eds. C. Gnecco and P. Ayala. London; New York: Routledge, 289-94.

Pairican, F. and M.J. Urrutia, 2021: The permanent rebellion: An interpretation of Mapuche uprisings under Chilean colonialism, Radical Americas 6(1). DOI: 10.14324/111.444.ra.2021.v6.1.012.

Pétursdóttir, P. and B. Olsen, 2018: Theory adrift: The matter of archaeological theorizing, Journal of Social Archaeology 18(1), 97-117.

Politis, G., 2001: On archaeological praxis, gender bias and indigenous peoples in South America, Journal of Social Archaeology 1(1), 90-107.

Pollock, S., R. Bernbeck, C. Jauß, J. Greger, C. von Rüden and S. Schreiber, 2014: Entangled discussions: Talking with Ian Hodder about his book Entangled, Forum Kritische Archäologie 3, 151-61.

Preucel, R.W., 2020: In defence of representation, World Archaeology 52(3), 395-411.

Preucel, R.W., 2021: The Predicament of Ontology, Cambridge Archaeological Journal 31(3), 461-67.

Radcliffe, S.A., 2014: Plural knowledges and Modernity: Social difference and geographical explanations, in Traditional Wisdom and Modern Knowledge for the Earth's Future, eds. K. Okamoto and Y. Ishikawa. Tokyo: Springer, 79-102.

Ramos, A.R., 1994. The hyperreal Indian, Critique of Anthropology 14(2), 153-71.

Ramos, A.R., 2012: The politics of perspectivism, Annual Review of Anthropology 41, 481-94.

Rivera Cusicanqui, S., 1987: El potencial epistemológico y teórico de la historia oral: de la lógica instrumental a la descolonización de la historia, Temas Sociales 11, 49-64.

Rivera Cusicanqui, S., 2010: Ch’ixinakax Utxiwa: Una reflexión sobre prácticas y discursos descolonizadores. Buenos Aires: Tinta Limón.

Simpson, L.B. and N. Klein, 2013: Dancing the world into being: A conversation with Idle No More's Leanne Simpson, Yes Magazine: https://bit.ly/2L2gYQ5. Accessed 05/04/2019.

Smith, C., V. Copley Sr and G. Jackson, 2018. Intellectual soup: On the reformulation and repatriation of Indigenous knowledge, in Shared knowledge, shared power: Engaging local and Indigenous heritage, ed. V. Apaydin. Cham: Springer, 9-28.

Smith, C. and H.M. Wobst (eds.), 2005: Indigenous archaeologies: Decolonising theory and practice. Oxon: Routledge.

Smith, L.T., 1999: Decolonizing methodologies. Research and Indigenous peoples. London: Zed Books.

Spivak, G.C., 1985: Three women's texts and a critique of imperialism, Critical Inquiry 12(1), 243-61.

Spivak, G.C., 1988a: Can the Subaltern Speak?, in Marxism and the interpretation of culture, eds. C. Nelson and L. Grossberg. Urbana: University of Illinois Press, 271-313.

Spivak, G.C., 1988b: Introduction. Subaltern Studies: Deconstructing historiography, in Selected Subaltern Studies, eds. R. Guha and G.C. Spivak. New York: Oxford University Press, 3-32.

Spivak, G.C., 2005: Scattered speculations on the subaltern and the popular, Postcolonial Studies 8(4), 475-86.

Sundberg, J., 2014: Decolonizing posthumanist geographies, Cultural Geographies 21(1), 33-47.

Thomas, J., 2015: The future of archaeological theory, Antiquity 89(348), 1287-96.

Todd, Z., 2016: An Indigenous feminist's take on the ontological turn: 'Ontology' is just another word for colonialism, Journal of Historical Sociology 29(1), 4-22.

Wainberg, R., 2021: Women's 'exchange' in Western and Amerindian societies: a feminist critique of perspectival anthropology, Feminist Theory: https://doi.org/10.1177/14647001211009006

Watts, C., 2013: Relational archaeologies: Humans, animals, things. London: Routledge.

Watts, V., 2013: Indigenous place-thought and agency amongst humans and non-humans (First Woman and Sky Woman go on a European Tour!), DIES: Decolonization, Indigeneity, Education and Society 2(1), 20-34.

Webmoor, T., 2007: What about 'one more turn after the social' in archaeological reasoning? Taking things seriously, World Archaeology 39, 563-78.

Wilkinson, D., 2017: Is there such a thing as Animism?, Journal of the American Academy of Religion 85(2), $289-311$.

Witmore, C., 2014: Archaeology and the New Materialisms, Journal of Contemporary Archaeology 1(2), 203-46.

Yampara Huarachi, S., 2011: Cosmovivencia andina. Vivir y convivir en armonía integral - Suma Qamaña, Bolivian Studies Journal/Revista de Estudios Bolivianos 18, 1-22.

Cite this article: Marín-Aguilera B (2021). Ceci n'est pas un subalterne. A Comment on Indigenous Erasure in OntologyRelated Archaeologies. Archaeological Dialogues 28, 133-139. https://doi.org/10.1017/S1380203821000234 